\title{
累積積分筋電図のリセット回数計測装置について
}

\author{
岡根 秀明 吉田耕一郎 津島 隆司 \\ 長沢 亨 津留 宏道
}

\section{A new Electrical Device for Integrated EMG Measurement}

\author{
Hideaki Okane, Koichiro Yoshida, Takashi Tsushima, \\ Tooru Nagasawa, Hiromichi Tsuru
}

\section{緒言}

筋電図積分值は筋活動を定量的に分析するうえにきわ めて有用である、積分值を得るには各種の方法がある が，原波形を累積積分計に通し，リセット回数を計測す る方法 1 5)が，現在のところ，測定精度および再現性の 点で優れている.

累積積分計の測定精度は, 積分感度を高くし, リセッ 卜回数を多くすればそれだけ向上するが, 逆にリセット 回数の計測に多大の時間と労力を要することになる.

そこで, われわれは積分計の精度を損うことなく, 多 数のリセット回数を自動的に計測する装置を開発し, 迅 速に積分值を求めることを可能にした．本論文では装置 の概要につけて報告する.

\section{装置}

図 1 は装置の全貌である. 前面パネルの(1)はパワース イッチである. (2) は 3 セグメントの表示器で, カウント したリセット回数をディジタル表示する. (3) は 2 セグメ ントの表示器で, カウントすべきバースト波の数（咀嚼 ストローク数)を(4) のキーボードによってプリセット するとここに表示される. 最大プリセット数は 99 であ る. (4) のクリアボタンによってプリセットを解除でき る.（5）はリセットスイッチで, (2)の表示をクリアす

広島大学歯学部歯科補棳学第 1 講座 (主任 : 津留宏道教授) Dept. of Removable Prosthodontics, Hiroshima Univ. Sch. of Dent. (Chief : Prof. Hiromichi Tsuru) 昭和 56 年 3 月 3 日受付
る.（6）は start/stop スイッチである.これを押した時 点からカウントが開始され, もう一度これを押せばカウ ントが停止する. 計測すべきストローク数をプリセット した場合には, 所定のストローク数に達すると自動的に カウントは停止する. 上面パネルの(7)は筋電図原波形の input, (8) はその output である. (9) は筋電図積分波形 の input, (10) は gate out である. (11) はトリガー信号の onset, offset 識別レベル調節ツマミ, (12) はパルス化した EMG 原波形の各パルスのインターバル識別装置で, こ れらによって EMG 原波形をトリガー信号に変換する (後述). (13) はトリガー信号の ON-OFF スイッチである.

\section{作動内容}

食品咀虂時の咀嚼筋表面筋電図は干涉波形のバースト 波として記録される.このバースト波の持続部分のみを 測定対象とするためには, バースト波の onset と offset を識別するためのトリガー信号が必要になる，本装置で

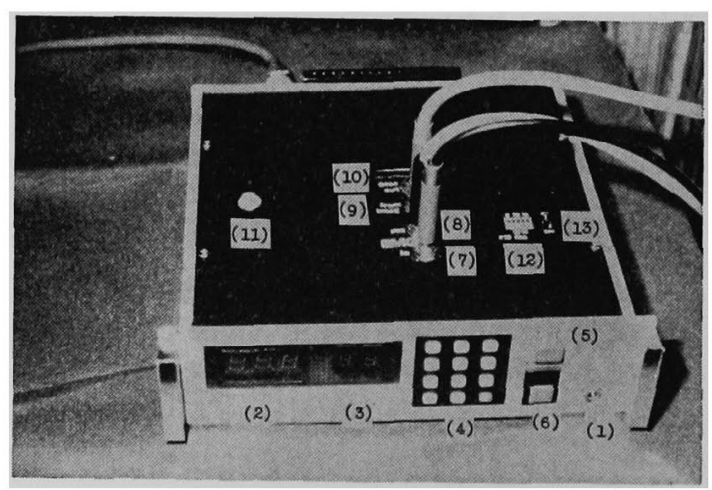

図 1 装置の全貌 


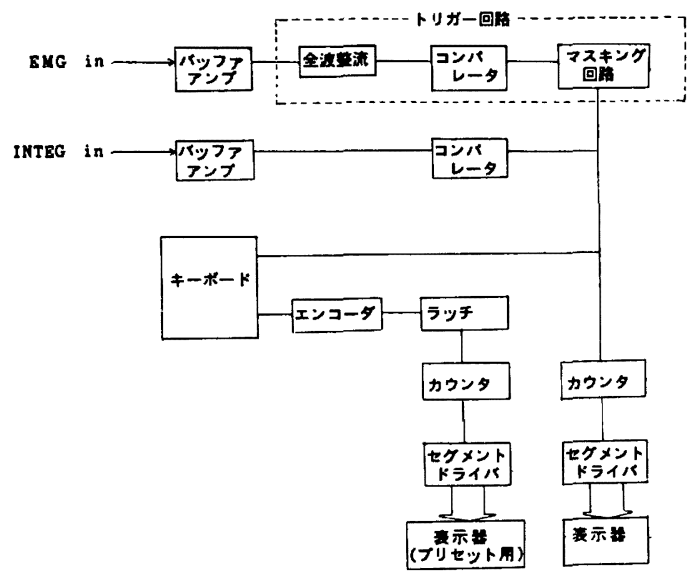

図 2 装置のブロック図

(A)

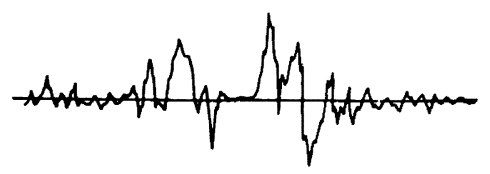

(B)

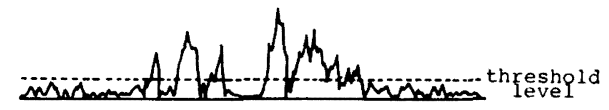

(C)

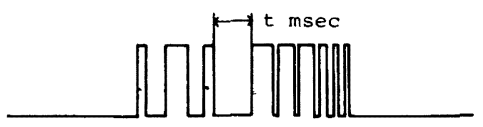

(D)

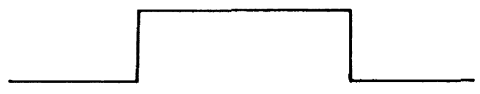

図 41 個のバースト波が 1 個のトリガー信号に変換され る様式を示す模式図.

(A) 原波形, (B) 全波整流波形, (C) パルス波形, (D) マスキ ング波形 (トリガー信号)

は積分する前の原波形をトリガー信号として用いた．図 2 は本装置のブロック図である．筋電図原波形とその累 積積分波形を本装置にパラレルに入力する．原波形を全 波整流し，後述のトリガー回路によって図 3 に示すよう に 1 個のバーストに対し 1 個のトリガー信号を発生させ る.このトリガー信号によって積分波形をコンパレート し，バースト波の持続に相当する部分のみ,リセット回 数をカウントする.プリセットされたバースト波の数だ けリセット回数を積算して，表示器にリセット総数が表 示される.

カウンターにはテキサスインストルメント社製の 10 進カウンターを用いた. リセット回数のカウンターとし
(A)

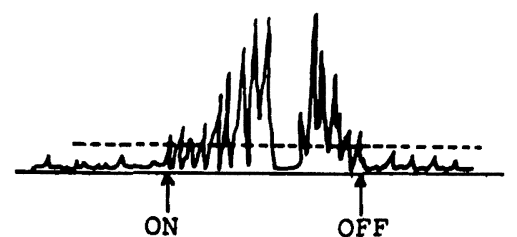

(B)

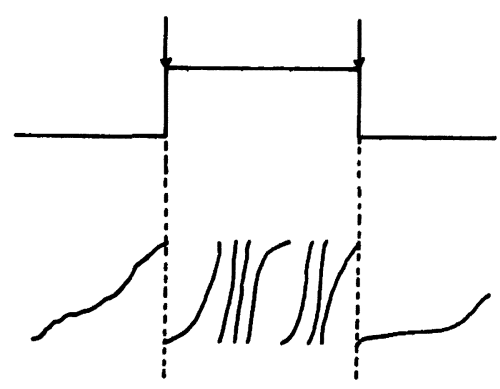

図 3 原波形を全波整流しトリガー信号に変換する. トリガー信号が ONの部分に相当する積分波形 のリセット回数をカウントする.

(A) 全波整流された原波形，(B) トリガー信号， (C) 櫴分波形

て SN 7490 型, プリセット数のカウンターとして $74 \mathrm{LS}$ 192 型を用いた. リセット回数はアップカウント，プリ セット数はダウンカウントされる. いずれもセグメント ドライバおよび表示器を組み合わせ，ディジタル回路を 構成した.

\section{トリガー回路について}

図 4 はトリガー信号の作り方を模式的に示したもので ある. (A) は本装置に入力された EMG 原波形の 1 個の バーストを示す.これを全波整流したものが (B)に示す 波形である，咀嚼筋表面筋電図では，バーストの間隔の 部分にも，通常，数 $10 \mu \mathrm{V}$ 程度の放電が認められる. そ こでこれよりわずかに高い電位に threshold level を 設定する.これは図 1 の (11)のツマミで 0 100 $\mu \mathrm{V}$ の間 に任意に設定できる. 設定 level を越えた波形をパルス 化したものが (C) の波形である。このパルス波形をマス キング回路に通し，(D) に示す 1 個のトリガー信号を得 る.すなわち, (D) のトリガー信号は (C) のパルス波の間 隔が $\mathrm{t} \mathrm{msec}$ 以下の場合, 1 つのパルスとしてマスキン グしたことを示す.この時間 $\mathrm{t}$ の設定は,あらかじめ図 1 の (12) によって行う. マスキングの時間設定は $30 \mathrm{msec,}$ $40 \mathrm{msec}, 50 \mathrm{msec}, 60 \mathrm{msec}$ の 4 段階である. 以上のよ うな原理によって，入力された管電図原波形は，そのバ 一スト波の数と同数のトリガー信号に変換され，これに 
(A)
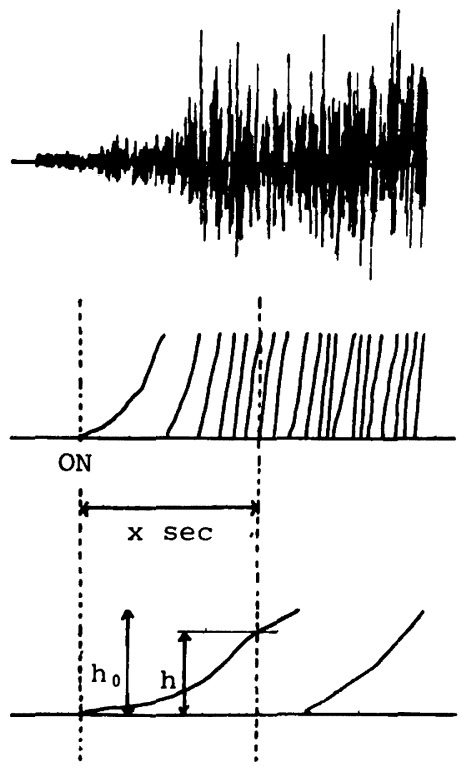

図 5 定常波の積分波形

（A）は積分感度が高い場合, (B) は積分感度を(A)の $1 / 10$ にした場合を示寸.

よって図 3 の下段に示す積分波形をコンパレートし，バ ースト波の持続に相当する部分のリセット回数がカウン トされる.

\section{考察}

筋の活動量を定量化するために積分筋電図が用いられ る. 積分值を得る方法としては (1) 平滑回路を用いる方 法 ${ }^{1,6 ~ 8)}$ ，(2) 累積積分計を用いる方法 ${ }^{1 \sim 5)}$, (3) 電解質中の イオンの移動量によって測定する方法")，(4) コンピュー 夕を用いて原波形を A-D 変換し, 棘波の面積を測定す る方法 ${ }^{10)},(5)$ コンピュータを用いてフーリエ変換し, エ ネルギー值として表示する方法 ${ }^{11}$, (6) 2 筋の筋電図を同 時に平滑回路に通し, ベクトル筋電図として表示する方 法 ${ }^{12)}$, その他各種の方法が発表されている.これらの中 で (2) の方法は筋の放電量を直接測定するもので, 他の 方法に比べ (1) 精度および再現性が優れている, (2) 市販 の累積積分計も多種あり，それ以外に特殊な装置は不要 である, (3) 計測法自体はリセット回数を数えるという単 純なものであり，測定が容易である等の利点を有し，応 用佂值が高い。しかしながら，食品咀緭の場合には多数 のストロークについてリセット回数を数えなければなら ず，多大の時間と労力を要するという欠点があった。 こ
(A)

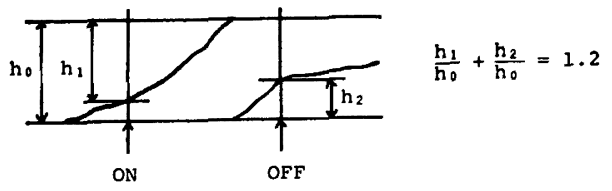

(B)

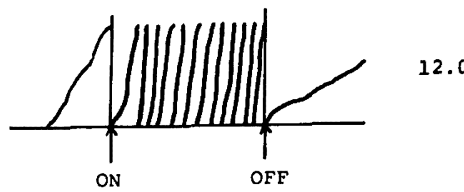

図 6 （B）は積分感度を(A)の10倍にした場合を示す。

の点を解決すれば，累積積分計の応用価値がさらに高ま るものと考え，本装置を開発した.

本装置は主に食品咀霹時のバースト波の積分值を計測 することを目的としているが，もちろん，咬みしめ時の ように定常波を積分する場合にも用いることができる. 図 5 の (A) に示すように測定したい時点で start/stop スイッチ（図1の6）を押し, 所定の時間の後, 再びこ のスイッチを押せば，その閒のリセット回数が表示され る.タイマーを併用すればより正確な測定が可能であろ う. しかし, 定常波の場合は図 5 の(B)のように, 積分感 度を低くし, $\mathrm{h} / \mathrm{h}_{0}$ を計算することでも積分值を容易に得 ることはできょう。

これに対し, 食品咀嚼時のバースト波の場合, 以下の ような困難性がある. (1) 1 個のバースト波の放電量が少 なく，しかも多数のバースト波を測定しなければならな い.(2) バースト波の持続部分のみを測定対象とすべき である.

(1)について

1 個のバースト波当たりの放電量が少ないため, 積分 感度を高くする必要がある. 図6の (A) のように感度が 低、場合, リセット回数を数えれば 2 となるが, 正確に 測定するためには $\left(\mathrm{h}_{1}+\mathrm{h}_{2}\right) / \mathrm{h}_{0}$ を計算しなければならず， 正しい値である 1.2 と比較するとかなり誤差が大きく なる.しかし, 食品咀嚼時の積分值を求める場合, 通常, 咀嚼中期 20 ストロークを対象とし，場合によっては咀 灀開始から燕下直前までの全ストロークを測定する必要 が生じる.われわれの過去2,3,5)の報告のように，被験筋 が複数でしかも実験条件が多数の場合，測定対象とすへ きバースト波の数は $5,000 \sim 20,000$ 以上にも及ぶ.この ような場合に, 図6の (A) のように1個のバーストにつ いて $\left(\mathrm{h}_{1}+\mathrm{h}_{2}\right) / \mathrm{h}_{0}$ を計算するのは容易なことではない. 図 6 の (B) は積分感度を (A)の 10 倍にしたものである.こ うすればリセット回数を数えるだけで測定精 度は 10 倍 
(A)

(B)

(c)

(D)

(E)

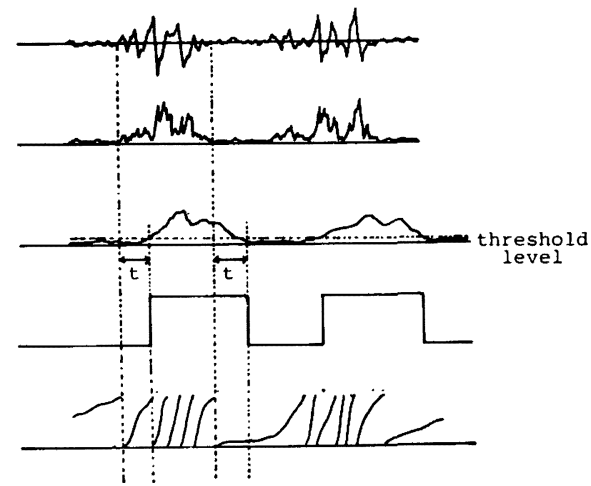

図 7 平滑回路を用いてトリガー信号を発生させると原波 形の onset, offset とトリガー信号の onset, off set に delay が生じる.

(A) 原波形, (B) 全波整流波形, (C) 平滑波形 (mean voltage 波形) (D) トリガー信号, (E) 積分波形

に高まるわけである. さらに感度を高め, リセット回数 を多くすればそれだけ測定精度が高まるが，単純にリセ ット回数を数えるだけでも，多大の時間と労力を要する ことになる.そこで本装置のような自動計測装置が必要 になる。

(2)について

食品咀嚼時の管電図では，バースト波の間隔の部分に もわずかな放電が認められ，この部分でも積分計の電位 が累積される，咀嚼筋活動を正確に評価するためには， 間隔の部分は測定対象とせず，バーストの持続部分のみ の積分值を求めるべきである，そのためにはバースト波 の onset, offsetを識別し,トリガー信号を発生させ, こ れによって積分波形をコンパレートする回路が必要であ る. 当初は図 7 に示すように，平滑回路を用いる方法を 考案した. すなわち EMG 原波形 (A) を全波整流 (B) し， 平滑回路を通して mean voltage 波形(C)にする, 破線 で示す threshold level を定め, onset, offset を識別し, トリガー信号 (D) に変換する．このトリガー信号によっ て積分波形(巨)の計測部を決定するわけである。このよう に平滑回路を用いると threshold level を設定するだけ で onset, offset を識別できる利点があるが，平滑回路 の time constant がかかるため,トリガー信号の onset, offset に delay (図 7 の ) が生じる.このため,リセット 回数をカウントする部位がずれ，正確な測定值が得られ なかった．そこで本装置では全波整流した波形（図 7 の B）をコンパレータによって直ちにパルス波に変換する 方法を用いた, 平滑回路を用いないため, threshold level を各棘波が越えるたびにパルスが発生し，バースト波の
数とパルスの数が一致しなくなり，プリセットしたバー ストの波の数だけカウントさせるのが不能となる．この 点を解決するため, 前項で説明したマスキング回路を付 加し， 1 個のバースト波を 1 個のトリガー信号に変換さ せるようにした。

以上のようにして本装置を実用化することを可能にし た結果, 咀礵筋活動量の分析がきわめて短時間で行える ようになり, 累積積分計の応用価值も高まり, 臨床診断 あるいは研究に大きく寄与するものと考える.

\section{まとめ}

累積積分計のリセット回数を自動的に計測する装置を 開発し, 装置の概要について説明した。

装置の試作にあたり多大のご協力をいただいた三栄測器社， 小林政博氏に感謝いたします。

本研究は昭和 55 年度文部省科学研究費 C-557451によった。 付記して感謝いたします.

\section{文献}

1) Ahlgren, J. : Mechanism of mastication, Acta. Odontol. Scand., 24, Suppl. $44: 1 \sim 109,1966$.

2）佐々木元：総義歯の床形態が咀嚼機能に及ぼす影響に関 する研究, 補緅誌, $22: 844 \sim 864,1978$.

3) Nagasawa, T., Okane, H. and Tsuru, H.: The role of the periodontal ligament in overdenture treatment, J. Prosthet. Dent., 42 : 12 16, 1979.

4) Okane, H., Yamashina, T., Nagasawa, T. and Tsuru, H. : The effect of anteroposterior inclination of occlusal plane on biting force, J. Prosthet. Dent., $42: 497 \sim 501,1979$.

5）岡根秀明：総義歯の咬合障害が咀罚筋活動に及ぽす影響 に関する研究，広大歯誌，12：196 212, 1980 .

6) Hickey, J.C., Woelfel, J.B. Allison, M.L. and Boucher, C.O. : Influence of occlusal schemes on the muscular activity of edentulous patients, J. Prosthet. Dent., 13:444 451, 1963.

7) 岡根秀明, 橋田博文, 津島隆司, 佐々木元, 長沢 亨, 津留宏道 : 総義歯の床面䅡が咬合力の発現に及ぼす影響 に関する実験的研究, 補緅誌, $23: 428 \sim 436,1979$.

8) Ingervall, B. and Hedegård, B. : An electromyographic study of masticatory and lip muscle function in patients with complete dentures, J. 
Prosthet. Dent., $43: 266 \sim 271,1980$.

9) Christensen, L.V. : Effect of an occlusal splint on integrated electromyography of masseter muscle in experimental tooth clenching in man, J. Oral Rehabil., $7: 281 \sim 288,1980$.

10）传々木元, 岡根秀明, 長沢 亨, 津留宏道: コンピュー ターを応用した咀礵筋筋電図のアナログ分析法, 補経
誌, $23: 384,1979$.

11）舷島宗弘：表面矨電困の周波数分析的データ処理とその 臨床医学的応用, 北関東医学, $21: 292 \sim 319,1971$.

12）山科透, 荒田斎, 棟久信宏, 長沢 亨, 津留宏道: 竻電図分析法に関する新考案一ベクトル能電図法につい て, 補緅誌, $21 ： 520 \sim 524,1977$. 